\title{
Monitoring and modelling landscape dynamics
}

\author{
Thomas Houet • Peter H. Verburg • \\ Thomas R. Loveland
}

Received: 28 September 2009/ Accepted: 5 October 2009/Published online: 20 October 2009

(C) Springer Science+Business Media B.V. 2009

\section{Introduction}

Changes in land cover and land use are among the most pervasive and important sources of recent alterations of the Earth's land surface. Land changes significantly affect key aspects of Earth System functioning, for example in contributing to local and regional climate change as well as to global climate warming, impacting biodiversity and water quality, or increasing soil degradation (Vitousek et al. 1997; Stohlgren et al. 1998; Houghton et al. 1999). Landscape dynamics studies integrating human-environment interactions and related to environmental issues have become increasingly important. Over the years these studies moved away from a focus on detecting and identifying land use and land cover changes (Loveland et al. 1999, 2002; Lambin et al. 2001) and understanding driving forces of landscape changes (Bürgi et al. 2004; Antrop

T. Houet $(\bowtie)$

GEODE, UMR CNRS 5602, Université Toulouse 2,

5 allée Antonio Machado, 31058 Toulouse Cedex 9,

France

e-mail: thomas.houet@univ-tlse2.fr

P. H. Verburg

Land Dynamics Group, Wageningen University,

PO Box 47, 6700 AA Wageningen, The Netherlands

T. R. Loveland

U.S. Geological Survey Earth Resources Observation and Science (EROS) Center, 47914 252nd Street,

Sioux Falls, SD 57198-0001, USA
2005) to modelling present land systems for predicting land cover changes (Veldkamp and Lambin 2001; Corgne et al. 2004; Hepinstall et al. 2008) and exploring possible futures of landscapes (Verburg et al. 2004; Kok et al. 2007). Such studies were and are still largely supported by national and international global environmental change programs such as the Land Use and Cover Change program (Lambin et al. 1999), the Global Land Project (GLP 2005), and the US Climate Change Research Program (Loveland et al. 2003). They contribute to improving the understanding of natural-human interactions and they advance monitoring and modelling of landscape dynamics needed to meet the challenges of land change science (Turner et al. 2007).

Monitoring landscape and land use/cover changes is considered as an essential first step to assist the identification of driving forces (Bürgi et al. 2004) and provide the data needed for modelling. Projection of futures landscape changes requires and understanding and integration of past landscape trends, current land change processes and feedbacks, and the incorporation of plausible assumptions or scenarios. Obviously, monitoring and modelling of landscape dynamics strongly depends on the scale and objectives of the planned applications. This, in turn, determines the different techniques needed. Thus, landscape change models should be appropriate for simulating identified social, economic, and ecological processes, and their dynamics and interactions that shape landscapes (Baker 1989; Gaucherel and Houet 2009). Land change 
models that are founded in land use theory and that consider land use history is also important and offer new opportunities for interdisciplinary research.

Landscape dynamics studies were and are often driven by disciplines other than landscape ecology although techniques and concepts from landscape ecology have consistently contributed to landscape change studies (Naveh 1991; Bürgi and Russell 2001; Antrop 2005). For example, the remote sensing community is regularly involved in monitoring landscape dynamics. Various disciplines, such as geography, offer diversified points of view and approaches that enable understanding the dynamics of landscape structure and function at different spatial and temporal scales. The need for the integration of landscape history, including past/current dynamics and feedbacks has been increasingly recognized (Caspersen et al. 2000; Nabuurs et al. 2003; Antrop 2005; Rhemtulla and Mladenoff 2007; Claessens et al. 2009; Gillson 2009). This special issue focuses on multidisciplinary research in land change science that illustrate how innovative data integration, analytical methods and techniques, and perspectives from geography, ecology, agronomy and computer sciences can help foster cross-disciplinary research with landscape ecologists (Hobbs 1997).

This special issue adds to the existing literature on the state of the art on landscape dynamics studies (Lambin and Geists 2006; Kok et al. 2007; Turner et al. 2007; Milne et al. 2009). It also illustrates both current advances and challenges for monitoring and modelling landscape dynamics. Selected papers in this volume illustrate key dimensions of land change science, highlight possible new directions of research such as the reinforcement of multi-scale (Verburg 2006) or human/nature (Milne et al. 2009) modelling approaches, and present integrated approaches to project future landscape changes (Kok et al. 2007). Most of the papers in this issue were selected from presentations at the international symposium "Spatial landscape modelling: from dynamic approaches to functional evaluations" that took place in Toulouse (France) from 3rd to 5th of June 2008 (http://w3.geode.univ-tlse2.fr/rtp-modelisation/).

\section{Monitoring and modelling landscape dynamics: current practices, limits and new directions}

Monitoring landscape dynamics is essential for understanding the complex interactions between social, environmental and geophysical processes (Munroe and Müller 2007). Land use and land cover change studies are often based on information on landscape structure and composition at different spatial and temporal resolution that is derived from remotely sensed data (Loveland et al. 2000; Goetz 2007; Coops et al. 2009). However, there are several challenges associated with developing the remote sensing inputs needed to understand landscape dynamics. The first challenge is to maintain continuous time series of low cost imagery (Turner et al. 2007). The planned 2012 launch of the Landsat Data Continuity Mission, for example, extends the Landsat record an additional 5-10 years. New data acquisition systems with high spatial and temporal resolutions (i.e. Formosat, $\mathrm{VEN} \mu \mathrm{S}$ missions) are also extremely promising sources of remotely sensed data that will further enable monitoring landscape dynamics at fine spatial and temporal scales. Improvement of techniques combining multi-scale/multi-sensors/ multi-source data studies show potential to rescale land cover data (Gardner et al. 2008) in order to improve common landscape monitoring methods. New direction to better understand landscape dynamics include moving from land cover to land use systems such as the detection of cropping systems. The paper of Lazrak et al. (2009) in this volume lays out an innovative use of data mining techniques to detect landscape regularities over time.

This special issue also presents new directions in modelling landscape dynamics. Agent-based models have primarily been used to simulate local land use and land cover changes processes with a focus on decision making (Parker et al. 2003; Bousquet and Page 2004; Matthews et al. 2007; Le et al. 2008). Valbuena et al. (2009) present an agent-based modelling approach that is also applicable at the regional scale and links individual decision making to changes in landscape structure. Innovation is not only found in new or improved models, but also in the combination of existing models. Gaucherel et al. (2009) reports on research in which multiple processbased models are coupled to evaluate ecological and aesthetic impacts of landscape changes. Verburg et al. (2009) illustrate the application of multiple models at different scales to explore possible landscape trajectories in Europe. Along with Valbuena et al. (2009), Sohl et al. (2009), and Houet et al. (2009), Verburg et al. (2009) point out the need for 
improved integrated land change models that connect local-to-global scales and land use pattern with land use change processes. If models are becoming more and more efficient to simulate processes at multiple scales, there is an obvious strong convergence between local scales models attempting to take into account global driving forces and regional/global models looking for finer spatial rendering at elementary landscape units (Castella et al. 2007; Sohl et al. 2007; Verburg et al. 2008).

The papers in this issue also highlight land change science challenges associated with improved prediction of land use change (Lambin et al. 2001), better integration of the land system (Kok et al. 2007), and the need for advanced scenario-based studies (Verburg et al. 2006). Sohl et al. (2009) and Houet et al. (2009) each propose a framework, at regional and local scales respectively, to include landscape trends and histories, to choose, parameterize, and validate models, and to explore multiple land change scenarios. Whatever the spatial scale of such approaches, data availability remains an ongoing challenge thus reinforcing the importance of landscape monitoring using multisource data (historical maps, remotely sensed data, etc.). Gibon et al. (2009) illustrates the need for an integrated and participatory approach that considers socio-ecological processes in the modelling and elaboration of scenarios. Regarding exploration of alternative land change futures, Verburg et al. (2009) assess possible future landscape changes based on contrasted scenarios. This provides a good indicator of likely future land configurations. This future dimension of landscape dynamic studies provides a helpful tool to delimit the envelope of possible landscape futures and to define the plausibility of the occurrence of futures landscape changes.

Finally, all of the papers in this special issue indicate that 'standard' monitoring and modelling techniques are not always valid or the most appropriate. Land cover monitoring does not always detect subtle changes within the landscape, e.g. changes in landscape elements and change in land management practices. Models should better represent such subtle landscape changes given the importance of such changes for the functioning of the landscape (Houet et al. 2009). At the same time land use (cropping) systems that show specific landscape temporal patterns and cycles that are not easily observed from traditional land cover data, but have importance for the dynamics in the landscape (Lazrak et al. 2009). Moreover, landscape dynamics studies need to go further in combining modelling approaches and techniques (Gaucherel et al. 2009; Gibon et al. 2009; Sohl et al. 2009; Valbuena et al. 2009) and projecting landscape dynamics to reduce uncertainties of the futures of landscape (Houet et al. 2009; Verburg et al. 2009). The temporal dimension of landscapes has to be considered as important as the spatial dimension in order to monitor, model, and assess human/nature interactions. Collectively, these considerations open new directions for research in land change science.

Acknowledgments This special issue is one of the results of the symposium "Spatial landscape modelling: from dynamic approaches to functional evaluations" that occurred in Toulouse in June 2008, supported by the French Thematic Interdisciplinary Network on «Landscape and Environment» of the department Human and Social Sciences of CNRS (National Centre for Scientific Research), the Region Midi-Pyrénées, the Toulouse Le Mirail University and the GEODE UMR 5602 CNRS. We would like to warmly thank all the reviewers that have contributed to this issue by their constructive comments.

\section{References}

Antrop M (2005) Why landscapes of the past are important for the future? Landsc Urban Plan 70:21-34

Baker WL (1989) A review of models of landscape change. Landscape Ecol 2:111-135

Bousquet F, Page Le (2004) Multi-agent simulations and ecosystem management: a review. Ecol Model 176:313-332

Bürgi M, Russell EWB (2001) Integrative methods to study landscape changes. Land Use Policy 18:9-16

Bürgi M, Hersperger AM, Schneeberger N (2004) Driving forces of landscape change-current and new directions. Landscape Ecol 19:857-868

Caspersen JP, Pacala S, Jenkins J, Hurtt G, Moorcroft P, Birdsey R (2000) Contribution of land-use history to carbon accumulation in U.S. forest. Science 290:1148-1151

Castella JC, Kam SP, Quang DD, Verburg P, Hoanh CT (2007) Combining top-down and bottom-up modelling approaches of land use/cover change to support public policies: Application to sustainable management of natural resources in northern Vietnam. Land Use Policy 24:531-545

Claessens L, Schoorl JM, Verburg PH, Geraedts L, Veldkamp A (2009) Modelling interactions and feedback mechanisms between land use change and landscape processes. Agric Ecosyst Environ 129(1-3):157-170

Coops NC, Wulder MA, Iwanicka D (2009) Demonstration of a satellite-based index to monitor habitat at continentalscales. Ecol Indic 9(5):948-958

Corgne S, Hubert-Moy L, Dézert J, Mercier G (2004) Land cover change prediction with a new theory of plausible 
and a paradoxical reasoning. In: Smarandache F, Dezert J (eds) Advances and applications of DSmT for information fusion, Am. Res. Press, Rehoboth

Gardner RH, Lookingbill TR, Townsend PA, Ferrari J (2008) A new approach for rescaling land cover data. Landscape Ecol 23:513-526

Gaucherel C and Houet T (2009) Preface to the selected papers on spatially explicit landscape modelling: current practices and challenges. Ecol Modell, doi: 10.1016/j.ecolmodel. 2009.06.025

Gaucherel C, Griffon S, Misson L and Houet T (2009) Combining process-based models for future biomass assessment at landscape scale. Landscape Ecol (this issue) doi: 10.1007/s10980-009-9400-6

Gibon A, Sheeren D, Monteil C, Ladet S and Balent G (2009) Modelling and simulating change in reforesting mountain landscapes using a social-ecological framework. Landscape Ecol (submitted)

Gillson L (2009) Landscapes in time and space. Landscape Ecol 24:149-155

GLP (2005) Science plan and implementation strategy. IGBP Report No. 53/IHDP Report No. 19. IGBP Secretariat, Stockholm. 64 pp. online: http://www.globallandproject. org/Documents/report_53.pdf (accessed March 2009)

Goetz S (2007) Crisis in Earth observation. Science 315:17671767 doi:10.1126/science. 1142466

Hepinstall JA, Alberti M, Marzluff JM (2008) Predicting land cover change and avian community responses in rapidly urbanizing environments. Landscape Ecol 23:1257-1276

Hobbs R (1997) Future landscapes and the future of landscape ecology. Landsc Urban Plan 37:1-9

Houet T, Loveland TR, Hubert-Moy L, Gaucherel C, Napton D, Barnes CA Sayler KL (2009) Exploring subtle land use and land cover changes: a framework for future landscape studies, Landscape Ecol (this issue) http://dx.doi.org/10. 1007/s10980-009-9362-8

Houghton RA, Hackler JL, Lawrence KT (1999) The US carbon budget: contributions from land-use change. Science 285:574-578

Kok K, Verburg P, Veldkamp T (2007) Integrated assessment of the land system: the future of land use. Land Use Policy 24:517-520

Lambin EF, Geists H (2006) Land-use and land-cover change. Local processes and global impacts, global change-The IGBP Series. Springer, Heidelberg, p 222

Lambin EF, Baulies X, Bockstael N, Fischer G, Krug T, Leemans R, Moran EF, Rindfuss RR, Sato Y, Skole D, Turner BL Vogel C (1999) Land-use and land-cover change (LUCC): implementation strategy, IGBP, Stockholm/Bonn

Lambin EF, Turner BL, Geist HJ, Agbola SB, Angelsen A, Bruce JW, Coomes OT, Dirzo R, Fischer G, Folke C, George PS, Homewood K, Imbernon J, Leemans R, Li XB, Moran EF, Mortimore M, Ramakrishnan PS, Richards JF, Skanes H, Steffen W, Stone GD, Svedin U, Veldkamp T, Vogel C, Xu JC (2001) The causes of landuse and land-cover change: moving beyond the myths. Global Environ Change Hum Policy Dim 11:261-269

Lazrak G, Mari JF Benoit M (2009) Landscape regularity modelling for environmental challenges in agriculture. Landscape Ecol (this issue) doi:10.1007/s10980-009-9399-8
Le QB, Park SJ, Vlek PLG, Cremers AB (2008) Land-use dynamic simulator (LUDAS): a multi-agent system model for simulating spatio-temporal dynamics of coupled human-landscape system. I. Structure and theoretical specification. Ecol Informatics 3:135-153

Loveland TR, Estes JE, Scepan J (1999) Introduction: special issue on global land cover mapping and validation. Photogramm Eng Remote Sens 65(9):1011-1012

Loveland TR, Reed BC, Brown JF, Ohlen DO, Zhu J, Yang L, Merchant JW (2000) Development of a global land cover characteristics database and IGBP DISCover from 1-km AVHRR Data. Int J Remote Sens 21(6-7):1303-1330

Loveland TR, Sohl TL, Stehman SV, Gallant AL, Sayler KL, Napton DE (2002) A strategy for estimating the rates of recent United States land-cover changes. Photogramm Eng Remote Sens 68:1091-1099

Loveland TR, Gutman G, Buford M, Chatterjee K, Justice CJ, Rogers C, Stokes B, Thomas J (2003) Land use/land cover change, In strategic plan for the climate change science program. U.S. Climate Change Science Program, Washington, DC 118-134

Matthews R, Gilbert N, Roach A, Polhill J, Gotts N (2007) Agent-based land-use models: a review of applications. Landscape Ecol 22:1447-1459

Milne E., Aspinall RJ Veldkamp TA (2009) Integrated modelling of natural and social systems in land change science. Landscape Ecol doi:10.1007/s10980-009-9392-2

Munroe DK, Müller D (2007) Issues in spatially explicit statistical land use/cover change (LUCC) models: examples from western Honduras and the Central Highlands of Vietnam. Land Use Policy 24:521-530

Nabuurs GJ, Schelhaas MJ, Mohren GMJ, Field CB (2003) Temporal evolution of the European forest sector carbon sink from 1950 to 1999. Glob Chang Biol 9:152-160

Naveh Z (1991) Some remarks on recent developments in landscape ecology as a transdisciplinary ecological and geographical science. Landscape Ecol 5:65-73

Parker DC, Manson SM, Janssen MA, Hoffmann MJ, Deadman P (2003) Multi-agent systems for the simulation of land use and land use change: a review. Ann Assoc Am Geogr 93:314-337

Rhemtulla JM, Mladenoff DJ (2007) Why history matters in landscape ecology. Landscape Ecol 22:1-3

Sohl TL, Sayler KL, Drummond MA, Loveland TR (2007) The FORE-SCE model: a practical approach for projecting land use change using scenario-based modeling. J Land Use Sci 2:102-126

Sohl TL, Loveland TR, Sleeter BM, Sayler KL Barnes CA (2009) Addressing foundational elements of regional land-use change forecasting. Landscape Ecol (this issue) doi:10.1007/s10980-009-9391-3

Stohlgren TJ, Chase TN, Pielke RA, Kittel TGF, Baron JS (1998) Evidence that local land use practices influence regional climate and vegetation patterns in adjacent natural areas. Glob Chang Biol 4:495-504

Turner BL II, Lambin EF, Reenberg A (2007) The emergence of land change science for global environmental change and sustainability. PNAS 104(52):20666-20671

Valbuena D, Verburg P, Bregt AK Ligtenberg A (2009) An agent-based approach to model land-use change at a 
regional scale. Landscape Ecol (this issue) doi:10.1007/ s10980-009-9380-6

Veldkamp A, Lambin EF (2001) Predicting land-use change. Agric Ecosyst Environ 85:1-6

Verburg PH (2006) Simulating feedback in land use and land cover change models. Landscape Ecol 21(8):1171-1183

Verburg P, Schot P, Dijst MJ, Veldkamp A (2004) Land use change modelling: current practice and research priorities. GeoJournal 61(4):309-324

Verburg P, Rounsevell MDA, Veldkamp TA (2006) Scenariobased studies of future land use in Europe. Agric Ecosyst Environ 114(1):1-6
Verburg P, Eickhout B, van Meijl H (2008) A multi-scale, multi-model approach for analyzing the future dynamics of European land use. Ann Reg Sci 42:57-77

Verburg P, van Berkel DB, van Doorn AM, van Eupen EM van den Heiligenberg HARM (2009) Trajectories of land use change in Europe: a model-based exploration of rural futures. Landscape Ecol (this issue) doi:10.1007/s10980009-9347-7

Vitousek PM, Mooney HA, Lubchenco J, Melillo JM (1997) Human domination of Earth's ecosystems. Science 277: 494-499 